\title{
PURIFICATION OF THE TOXIN IN A ZOANTHID PALYTHOA TUBERCULOSA
}

$\operatorname{AUTHOR}(S)$ :

Kimura, Shoji; Hashimoto, Yoshiro

\section{CITATION:}

Kimura, Shoji ...[et al]. PURIFICATION OF THE TOXIN IN A ZOANTHID PALYTHOA

TUBERCULOSA. PUBLICATIONS OF THE SETO MARINE BIOLOGICAL LABORATORY 1973, 20: 713-718

ISSUE DATE:

1973-12-19

URL:

http://hdl.handle.net/2433/175748

RIGHT: 


\title{
PURIFICATION OF THE TOXIN IN A ZOANTHID \\ PALYTHOA TUBERCULOSA ${ }^{1)}$
}

\author{
SHOJ KIMURA and YosHIRO HASHIMOTO \\ Laboratory of Marine Biochemistry, Faculty of Agriculture \\ The University of Tokyo, Tokyo, Japan
}

With 2 Text-figures

\section{Introduction}

In our previous papers, we reported that the zoanthid Palythoa tuberculosa contains a potent water-soluble toxin (НАSнIмото et al., 1969) and that its toxicity is closely connected with the presence of eggs in a polyp (Kimura et al., 1973). To characterize the toxin we attempted to purify it by ion exchange column chromatography and by gel filtration on Sephadex G-25. A preparation that killed mice at a dose of $0.6 \mu \mathrm{g} / \mathrm{kg}$ of body weight in intraperitoneal injection was finally obtained. It showed close similarity in pharmacological and chemical properties to palytoxin that was isolated from a related Palythoa species (Moore and Scheuer, 1971). This paper deals with the purification method and with some chemical properties of the purified toxin.

\section{Materials and Methods}

Specimens of $P$. tuberculosa were collected at Marcus Island in June 1970. They were frozen immediately after collection, transported by air to our laboratory, and kept at $-20^{\circ} \mathrm{C}$ until used. Most of the polyps in the specimens contained numerous ripe eggs which showed that the animals were in the reproductive phase, which coincided with a period of greatest toxicity.

The raw material was ground and extracted three times with hot $70 \%$ ethanol. The extracts were evaporated under reduced pressure to remove ethanol and the concentrate was washed with four equal volumes of diethyl ether. The diethyl ether extract was backwashed twice with water. The combined aqueous portion, after removal of dissolved diethyl ether under reduced pressure, was dialyzed against 20 times its volume of distilled water through a cellophane membrane.

The retentate was fractionated on a DEAE-celloluse column $(5.5 \times 30 \mathrm{~cm})$ and the combined toxic fractions were placed directly on a CM-cellulose column $(5.5 \times$

1) Studies on Marine Toxins-XXXVII. 
$25 \mathrm{~cm}$ ). Prior to use both columns were fully equilibrated with $0.02 \mathrm{M}$ sodium phosphate buffer and the toxin was eluted with the same buffer by collecting $200 \mathrm{ml}$ portions. The toxic fraction from the CM-cellulose column was evaporated to a small volume and passed through a Sephadex G-25 column $(6 \times 45 \mathrm{~cm})$ using $0.1 \mathrm{M}$ acetic acid as solvent.

For further purification, the crude toxin thus obtained was applied to a DEAESephadex A-25 column $(2.6 \times 45 \mathrm{~cm})$ equilibrated with $0.02 \mathrm{M}$ sodium phosphate buffer ( $\mathrm{pH}$ 6.9) and a CM-Sephadex C-25 column $(2.6 \times 45 \mathrm{~cm})$ equilibrated with 0.02 $\mathrm{M}$ sodium dihydrogen phosphate ( $\mathrm{pH} 4.6$ ). The samples were evaporated to dryness and each residue was dissolved in $5 \mathrm{ml}$ of the solution that had been used for equilibration of the column. By eluting with the same solution, $5 \mathrm{ml}$ fractions were collected. After each column chromatography, phosphate was removed from the eluates by a long column $(2.6 \times 90 \mathrm{~cm})$ of Sephadex G-25 and $0.1 \mathrm{M}$ acetic acid. By rechromatography on the Sephadex G-25 column, a highly purified toxin was obtained.

Elution of the toxin during chromatography and progress of the purification were monitored by mouse bioassay throughout and by uv absorption at $263 \mathrm{~nm}$ in all steps following DEAE-Sephadex column chromatography. For the mouse bioassay, a portion was taken from a given fraction and diluted with distilled water to a level of toxicity adequate to kill mice by intraperitoneal injection during a 30 to 120 minute interval. The amount of toxin (MU) in a fraction was determined from the average time-to-death of mice that was observed at this dilution and from the standard dosetime-to-death curve (HASHimoto et al., 1969). The toxicity of a preparation at each step of the purification was expressed as minimum lethal dose per $\mathrm{kg}$ body weight of mouse.

For thin layer chromatography, silica gel H (Merck) and Avicel SF (FMC Co.) were used as supporting media in combination with the solvent systems shown in Table 1. Spots were visualized by spraying with benzidine-periodate, anisaldehydesulfuric acid reagents, and 50 per cent sulfuric acid.

\section{Results}

Purification of the Toxin: In a typical run the hot 70 per cent ethanolic extract from $2 \mathrm{~kg}$ animals yielded $10.7 \mathrm{~g}$ of retentate with a toxicity of $30 \mu \mathrm{g} / \mathrm{kg}$. By subsequent cellulose ion exchange column chromatography, in which the toxic principles appeared in the percolates, a solid $(108 \mathrm{mg})$ with a toxicity of $1.0 \mu \mathrm{g} / \mathrm{kg}$ was obtained. This crude toxin was then fractionated on DEAE-Sephadex and CM-Sephadex columns. The elution pattern from the CM column is shown in Fig. 1. The toxic effluents (430$630 \mathrm{ml}$ ) were combined and condensed. The concentrate was subjected to a Sephadex G-25 column. By rechromatography on the same column, a purified toxin (solid $27.3 \mathrm{mg}$, toxicity $0.6 \mu \mathrm{g} / \mathrm{kg}$ ) was obtained. 


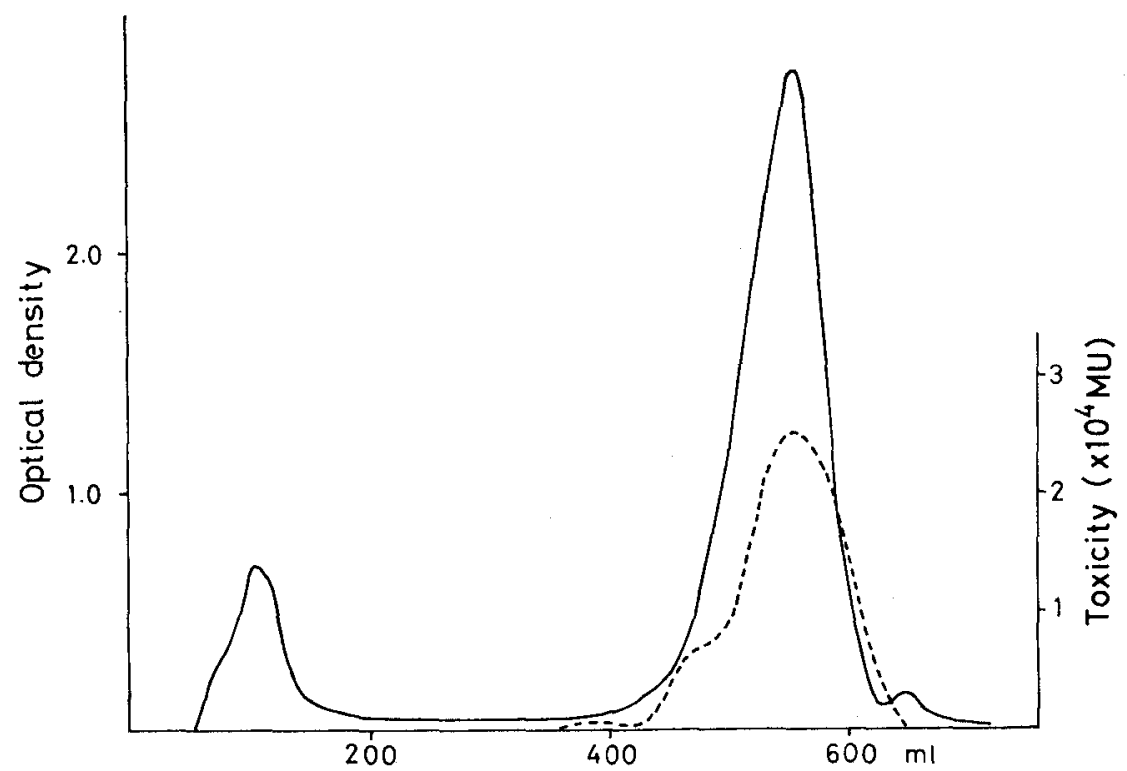

Fig. 1. Elution pattern from a CM-Sephadex column.

- Optical density at $263 \mathrm{~nm}$.

Toxicity (MU per $\mathrm{ml}$ of the fraction).

Properties of the Toxin: The purified preparation is a transparent and amorphous solid which has not yet been crystallized. It is soluble in water, slightly soluble in methanol, and insoluble in other common organic solvents. The toxin is stable in neutral solution, but labile in both alkaline and acidic solutions. Rf values on thin layer chromatographic plates are summarized in Table 1. Our preparation shows a

Table 1. Rf values of the toxin from $P$. tuberculosa and of palytoxin.

\begin{tabular}{cccc}
\hline & Solvent* & \multicolumn{2}{c}{ Rf value } \\
\cline { 3 - 4 } Adsorbent & system & Toxin from $P$. tuberculosa & Palytoxin \\
\hline & I & 0.47 & 0.47 \\
Silica gel H & II & 0.45 & 0.45 \\
& III & $0.62,0.38$ & $0.62,0.37$ \\
Avicel SF & IV & 0.39 & 0.41 \\
\hline
\end{tabular}

* I. ethyl acetate-pyridine-water $(2: 1: 2)$, II. n-butanol-pyridine-water $(9: 5: 8)$, III. n-amyl alcoholpyridine-water $(7: 7: 6)$, IV. n-butanol-acetic acid-water $(4: 1: 2)$.

good agreement with palytoxin obtained by courtesy of Dr. Scheuer, University of Hawaii. The spot with a lower $\mathrm{Rf}$ value ( $\mathrm{Rf} 0.38$ ) on silica gel $\mathrm{H}$, developed with solvent system III, is considered to be a degradation product that is formed during the development, and not a contaminant, because the fraction recovered from the toxic 
spot at $\operatorname{Rf} 0.62$ gave the same chromatogram revealing the same two spots. The toxin is positive to benzidine-periodate and anisaldehyde-sulfuric acid reagents and slightly so to ninhydrin, but negative to Dragendorff and Ehrlich reagents. Its uv spectrum exhibits maxima at 233 and $263 \mathrm{~nm}$ (Fig. 2). The uv spectrum of our preparation is very similar to that reported for palytoxin, although the intensities of the two uv peaks are slightly different perhaps because of the lower purity of our preparation.

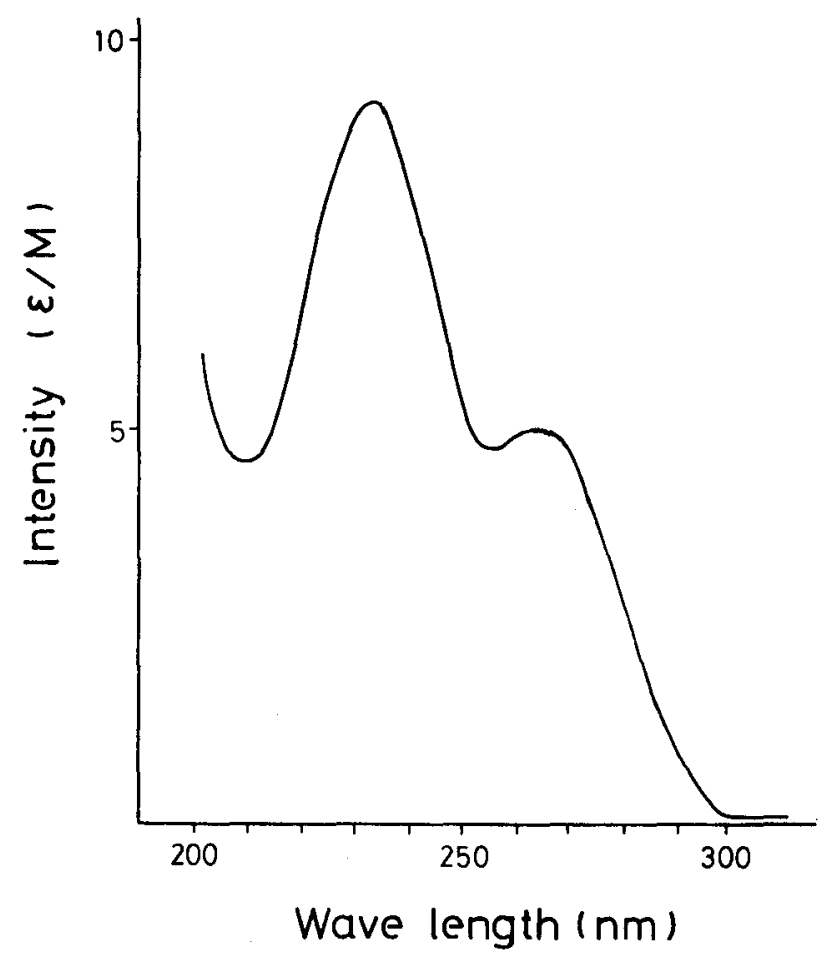

Fig. 2. Ultra-violet absorption spectrum of the toxin in water.

\section{Discussion}

A potent toxin, designated palytoxin, was reported in a closely related species "limu-make-o-Hana", tentatively identified as Palythoa sp. (MOORE and ScHEUER, 1971). As shown in Table 1, our toxin shows good agreement with the Rf values of palytoxin. Both toxins possess almost identical uv absorption. They show no appreciable difference in other chemical properties, such as sensitivity to $\mathrm{pH}$, retention volume on CM-Sephadex column, and reactions in qualitative tests, thus suggesting that they are very similar, if not identical.

The purified toxin showed a toxicity of $0.6 \mu \mathrm{g} / \mathrm{kg}$ in mice, far exceeding tetrodotoxin or saxitoxin. $P$. tuberculosa is one of the most abundant organisms in coral reef 
communities. In connection with the ciguatera phenomenon, it may be worth studying whether or not the toxin is transferred through the food chain from the zoanthid to fish.

\section{Summary}

The toxin in a zoanthid Palythoa tuberculosa was purified by column chromatography, on cellulose and Sephadex ion exchange, and by gel filtration on Sephadex G-25. The purified preparation killed mice at a minimum dose of $0.6 \mu \mathrm{g} / \mathrm{kg}$ body weight when injected intraperitoneally. Judging from the chemical properties, especially behavior on thin layer chromatography, it appears that the toxin is very similar, if not identical, to palytoxin from a closely related Palythoa species.

\section{Acknowledgements}

The authors are grateful to the Japan Meteorological Agency for collection of specimens at Marcus Island and to Dr. P. J. SCHeUer, University of Hawaii, for a kind supply of palytoxin and for assistance with this manuscript.

\section{REFERENCES}

Hashimoto, Y., N. Fusetani, and S. Kimura, 1969. Aluterin: a toxin of filefish Alutera scripta, probably originating from a zoanthid Palythoa tuberculosa. Bull. Jap. Soc. Sci. Fish., 35, pp. 1086-1093.

Kimura, S., Y. Hashimoto, and K. Yamazato, 1973. Toxicity of the zoanthid Palythoa tuberculosa. Toxicon, 10, pp. 611-617.

Moore, R. E. and P. J. Scheuer, 1971. Palytoxin: A new marine toxin from a coelenterate. Science, 172 , pp. $495-498$.

\section{DISCUSSION}

RANDALL: What is the distribution of Palythoa tuberculosa within the reef complex? In wha reef zone is it more commonly found?

Kimura and Yamazato: They are found on the reef flat near the edge, forming extensive beds at certain areas.

Ross: Were eggs collected and toxin extracted separately from eggs in order to ascertain whether the toxin comes from the eggs or from the rest of the animal? Your observation that more toxin is present when eggs are present is surprising, and especially your suggestion that the toxin is contained in the eggs.

KimURA and HASHimoto: We found that the isolated eggs were highly toxic and the toxicity was closely connected with maturation of female polyps (Toxicon, 1973). The male and sterile polyps were all nontoxic. For purification we used the colonies containing much matured female polyps without dissecting into parts. 
MülLeR: Firstly, have you any idea to which chemical class palytoxin belongs? Secondly, is there any similarity between palytoxin and tetrodotoxin?

Kimura and Hashimoto: We have not yet studied structure of the toxin. Palytoxin was reported by Dr. SCHEuER to have a molecular weight of approximately 3000 , to contain no respective amino acid or sugar units, and to be low in nitrogen and high in oxygen contents. Palytoxin is quite different from tetrodotoxin in all aspects of chemical and pharmacological properties.

TокıокA: Are there any marine animals which are poisoned by that very strong palytoxin in natural environments?

Hashimoto: We may be poisoned indirectly if we eat the meat of Tridacna which has taken eggs of Palythoa tuberculosa. 